\title{
РЕЗУЛЬТАТИ ЕКСПЕРИМЕНТАЛЬНОЇ ПЕРЕВІРКИ ЕФЕКТИВНОСТІ ПСИХОЛОГО-ОРГАНІЗАЦІЙНОЇ ТЕХНОЛОГІї \\ З РОЗВИТКУ КОНСТРУКТИВНОЇ КОПІНГ-ПОВЕДІНКИ ПРАЦІВНИКІВ ОРГАНІВ ВНУТРІШНІХ СПРАВ
}

УДК: 159.944 .4

\section{Дідух Марина Миколаӥвна}

Викладач кафедри психології та педагогіки Національної академії внутрішніх справ, м. Київ (Украӥна)

\begin{abstract}
Анотація. $\quad$ в статті представлені результати формуючого експерименту, щзо полягав у розробиі науково-обтрунтованих засобів розвитку конструктивності копінг-поведінки працівників органів внутрішніх справ у важких ситуаціях професійної діяльності та експериментальної перевірки їх ефективності. В основу спеціальної психолого-організаційної технології «Розвиток конструктивної копінг-поведінки працівників органів внутрішніх справ у важких ситуачіях професійної діяльності», було покладено психолого-організаційну технологію, запропоновану Л. М. Карамушкою. Мета технологї полягала у забезпеченні самозмінювання $i$ корегування копінг-поведінки учасників тренінгу у напрямі вибору конструктивних копінгстратегій. Результати експерименту свідчать, щзо після застосування психолого-організаційної технологї̈ статистично значимі зміни відбулися за більшістю діагностованих показників.
\end{abstract}

Ключові слова: психолого-організаиійна технологія, копінг-поведінка, конструктивна копінг-поведінка, моделі копінг-поведінки, діагностико-інтерпретаційний компонент інформаційно-смисловий компонент технологї, технології.

Постановка проблеми та ії зв'язок 3 важливими практичними завданнями

Професійне функціонування працівників органів внутрішніх справ $є$ емоційно напруженим видом соціальної активності і входить до групи професій $з$ постійним впливом негативно виражених стресорів. Показниками професійного стресу виступають висока схильність правоохоронців до психосоматичних, невротичних та інших межових станів та пато- логій. Високий рівень напруженості професійної діяльності вимагає від працівників органів внутрішніх справ значних резервів психіки, самовладання, навичок саморегуляції, що значно підвищує значення такого інтеграційного утворення, як копінг-поведінка. Тому, формування конструктивної копінг-поведінки відноситься до числа пріоритетних завдань психологічного супроводу правоохоронної діяльності. 
Останні дослідження і публікації, виділення невирішених питань загальної проблеми, якій присвячується стаття

На початку 2000-х років вивчення копінг-поведінки стає актуальним серед наукових досліджень вітчизняних учених. Аналіз сучасних літературних джерел показав, що предметом більшості наукових досліджень копінг-поведінки виступали психологічні особливості формування і застосування особистістю копінг-стратегій.

Так, вивченню копінг-ресурсів як чинників збереження професійного здоров'я представників екстрених служб присвячене дослідження В. В. Грандт [3].Локус контролю курсантів та офіцерів податкової служби в якості одного 3 основних базових копінгресурсів, що впливає на когнітивну оцінку емоційно-стресових ситуацій і реалізацію копінг-стратегій, спрямованих на подолання стресу, досліджував [10].О. С. Самара, вивчаючи психологічні особливості стратегій копінг-поведінки у співробітників МНС, визначив, що серед психологічних особливостей, які сприяють формуванню адаптивних копінг-стратегій, важливу роль відіграють успішність професійної адаптації і ступінь професійної реалізації, як середовищні ресурси долаючої поведінки [7].У роботі О. О. Назарова розкрито місце та роль індивідуальних ресурсів особистості у подоланні професійного стресу працівниками пожежно-рятувальних підрозділів МНС [6].У дослідженні О. І. Скленя встановлено кореляційний зв'язок між категорією стажу та ефективною формою копінг-поведінки працівників пожежно-рятувальних підрозділів МНС України, а також визначено, що на ефективність вибору копінг-стратегії впливає комунікативна сторона особистості, до якої відноситься вміння працювати в команді, здатність встановлювати та підтримувати контакти тощо [8].Проте, незважаючи на підвищений науково-практичний інтерес до проблеми копінгповедінки, питання формування конструктивної копінг-поведінки правоохоронців у психологічній науці залишається недостатньо вивченим, а пошук шляхів формування конструктивної копінг-поведінки правоохоронців постає актуальним науково-практичним завданням сьогодення.

\section{Формулювання цілей i постановка}

\section{завдань статті}

Метою статті є висвітлення основного змісту психолого-організаційної технології 3 розвитку конструктивної копінг-поведінки працівників органів внутрішніх справ у важких ситуаціях професійної діяльності та результатів експериментальної перевірки її ефективності.

Виклад методики і результатів дослідження

Результати аналізу наукової літератури $[1,2,4,5]$ дозволяють сформулювати важливі висновки:

$\Rightarrow$ характеристики копінг-поведінки праців- 
ників органів внутрішніх справ суттєво впливають на ефективність розв'язання важких ситуацій у їх професійній діяльностi;

$\Rightarrow$ конструктивність стратегій копінгповедінки, які обирають працівники органів внутрішніх справ для розв'язання важких ситуацій своєї професійної діяльності, залежить від таких особистісних характеристик як інтернальність локусу контролю, мотивація на досягнення успіху, емпатійність, афіліація, самоефективність, самооцінка, стиль саморегуляції тощо;

$\Rightarrow$ Структурні компоненти копінг-поведінки працівників правоохоронних органів у важких ситуаціях сформовані на середньому рівні;

$\Rightarrow$ рівень сформованості структурних елементів копінг-поведінки працівників органів внутрішніх справ у важких ситуаціях професійної діяльності свідчить про необхідність їх розвитку у напрямі надання більшої конструктивності;

$\Rightarrow$ конструктивність копінг-поведінки працівників органів внутрішніх справ у важких ситуаціях професійної діяльності можна підвищити психологічними засобами, шляхом створення умов для набуття необхідних знань, умінь, навичок, сприяння виробленню адекватної самооцінки і оцінки самоефективності, розвитку інтернальності, мотивації досягнення успіху, корегування мотивів афіліації, удосконалення арсеналу засобів саморегуляції власної поведінки [4].

Для розвитку конструктивної копінгповедінки працівників органів внутрішніх справ у важких ситуаціях було розроблено психолого-організаційну технологію «Розвиток конструктивної копінг-поведінки працівників органів внутрішніх справ у важких ситуаціях професійної діяльності». Л. М. Карамушка визначає психологоорганізаційну технологію як систему «... основних видів та форм діяльності організаційних психологів, спрямованих на вирішення певних психологічних проблем, пов'язаних як з діяльністю й розвитком організації в цілому, так і функціонуванням менеджерів і персоналу організацій...» [9, с.57]. Дослідниця включає до структури психологоорганізаційної технології такі основні компоненти:

a) інформаційно-смисловий компонент (теоретичні підходи до аналізу того чи іншого психологічного явища в організації);

б) діагностико-інтерпретаційний компонент (аналіз основних критеріїв та показників явища, що досліджується, ознайомлення 3 методами, які можуть бути використані для їх вимірювання, обгрунтування доцільності застосування тих чи інших діагностичних методів);

в) корекційно-розвивальний компонент (визначення основних видів тренінгів та стратегій здійснення консультування, обгрунту- 
вання доцільності використання індивідуальних або групових форм корекційнорозвивальної роботи в тих чи інших ситуаціях тощо).

Зміст психолого-організаційної технології було визначено на основі структурнофункціональної моделі копінг-поведінки працівників органів внутрішніх справ [1].Структурно-функціональна модель копінгповедінки працівників органів внутрішніх справ складається з трьох компонентів: когнітивно-оцінного, мотиваційно-операційного та регулятивного.

Мета психолого-організаційної технологіï полягала у забезпеченні самозмінювання і корегування копінг-поведінки учасників тренінгу у напрямі вибору конструктивних копінг-стратегій.

Основними завданнями технології бу$л и:$

1. Сформувати у працівників органів внутрішніх справ потребу у переважному виборі асертивної і про соціальної копінгстратегій (дій) для подолання важких ситуацій.

2. Збалансувати когнітивно-оцінний, мотиваційно-операційний та регулятивний компоненти копінг-поведінки.

3. Підготувати працівників органів внутрішніх справ до активного подолання за рахунок свідомої спрямованості копінгповедінки на джерело стресу, з метою його усунення.

\section{4. Розвинути особистісно-середовищні} копінг-ресурси працівників органів внутрішніх справ, що забезпечують сприятливий психологічний фон поведінки подолання і сприяють розвитку конструктивної копінгповедінки (самоефективність, самооцінку, сприйняття соціальної підтримки, інтернальний локус контролю над середовищем, емпатію тощо).

3 метою активізації пізнавальної діяльності учасників формуючого експерименту було використано різноманітні інтерактивні техніки: вивчення очікувань, спільна розробка правил групової роботи, «криголами», створення малих груп, заповнення робочих листків, «мозковий штурм», рольові ігри, тренінгові вправи, міні-лекції, аналіз професійних ситуацій, метод незавершених речень, групова дискусія тощо [9]. Зокрема, перед початком кожного заняття, 3 метою зняття емоційної напруги і створення робочої атмосфери, проводилася інтерактивна методика «криголам». Застосування «криголамів» дозволяло швидко налагодити взаємовідносини з групою, та створити необхідну емоційну атмосферу.

\section{Інформаційно-смисловий компонент} технології реалізовувався під час трьох лекційних та трьох семінарських занять. Їх метою був розвиток когнітивно-оцінного компоненту копінг-поведінки. Було прочитано лекції за такими темами: «Психологічна адаптація особистості: поняття, види, чинники, осо- 
бливості», «Копінг-поведінка і психологічний захист особистості», «Копінг-стратегії і ефективне функціонування професіонала». Основу для лекцій склали матеріали використані у роботі над дисертаційним дослідженням. На семінарах обговорювалися головні питання 3 лекційних занять.

\section{Діагностико-інтерпретаційний ком-} понент технології реалізовувався на практичному занятті на тему: «Діагностика копінгповедінки працівників органів внутрішніх справ у важких ситуаціях професійної діяльності». Під час заняття правоохоронцям, які увійшли до експериментальної групи, у формі міні-лекції було презентовано розроблену нами структурно-функціональну модель копінгповедінки, і розкрито зміст іiі компонентів. Учасників було ознайомлено з методиками, які були використані для вимірювання характеристик, що впливають на вибір копінгстратегії, обгрунтовано доцільність їх застосування для вимірювання параметрів моделі, та проведено перший діагностичний зріз. Заняття проводилося на основі матеріалів нашого дослідження.

Корекційно-розвивальний компонент технології складався 3 системи тренінгових занять, спрямованих на розвиток когнітивнооцінного, мотиваційно-операційного та регулятивного компонентів копінг-поведінки працівників органів внутрішніх справ. Для розробки тренінгових занять було використано модифікації вже відомих технік групової роботи.
Важливу роль у забезпеченні ефективності заходів усього корекційнорозвивального компоненту психологоорганізаційної технології відіграє перше заняття. Його основна мета: дати можливість учасникам групи познайомитися один з одним і з ведучим, визначити цілі і завдання програми, створити атмосферу взаєморозуміння i взаємної підтримки. Знайомство відбувалося у формі самопрезентації. Для полегшення знайомства застосовувалися ігрові прийоми.

Спільно з учасниками було розроблено правила групової роботи, які стали орієнтиром в організації взаємодії на заняттях:

1. Правило «тут і тепер» .

2. Правило «щирість і відкритість».

3. Правило «Я».

4. Правило «активність».

5. Правило «конфіденційність».

Після визначення правил, учасників було ознайомлено $з$ процесом групової роботи. Для встановлення в групі атмосфери довіри, комфорту та підтримки, подолання можливої тривоги і недовіри, що часто виникають на початку групової роботи, використовувався метод «мозкового штурму».

Технологія розвитку конструктивної поведінки працівників органів внутрішніх справ відноситься до технологій роботи організаційних психологів $з$ персоналом організацій (за термінологією Л. М. Карамушки[9]). Ефективність зазначеної психологоорганізаційної технології було перевірено екс- 
периментально. Для перевірки ефективності розробленої психолого-організаційної технології розвитку конструктивної копінгповедінки працівників органів внутрішніх справ у важких ситуаціях професійної діяльності було проведено формувальний експеримент, який складався 3 трьох етапів. На першому, підготовчому, етапі експерименту було проведено емпіричне дослідження (перший діагностичний зріз), за результатами якого було сформовано експериментальну (ЕГ) та контрольну (КГ) групи у складі 28 чоловік кожна. На другому етапі, реалізації, були проведені занятяя передбачені психологоорганізаційною технологією «Розвиток активної копінг-поведінки працівників органів внутрішніх справ у важких ситуаціях професійної діяльності». На третьому етапі, підсумковому, було проведено другий діагностичний зріз, та проаналізовано отримані результати.

Для підготовчого етапу актуальним було вирішення проблеми репрезентативності та обгрунтованості вибору методик, контингенту учасників експерименту і налагодження процедури збору інформації. Для забезпечення ідентичності характеристик учасників, при формуванні експериментальної і контрольної груп, були використані наступні методики:

- когнітивно-оцінний компонент моделі копінг-поведінки досліджувався за допомогою методики діагностики парціальних позицій інтернальності-екстернальності особистості (Є. Ф. Бажин, К. О. Голінкіна,
О. М. Еткінд), тесту визначення рівня самоефективності Дж. Маддукса і М. Шеєра (модифікаціяЛ. Бояринцевої);

- мотиваційно-операційний компонент моделі копінг-поведінки досліджувався за допомогою опитувальника «SACS» («Стратегії подолання стресових ситуацій») С. Хобфолла, тесту «Мотивація досягнення успіху» (Т. Елерс), тесту «Мотивація уникнення невдач» (Т. Елерс), методики з визначення мотивів афіліації (А. Мехрабіан);

- регулятивний компонент моделі копінгповедінки досліджувався за допомогою методики діагностики рівня емпатійних здібностей (В. В. Бойко), методики «Самооцінка особистості» у варіанті С. А. Будассі, методики«Стиль саморегуляції поведінки» (ССПМ)

В. І. Моросанової та О. М. Коноз.

Для встановлення тотожності характеристик учасників контрольної та експериментальної груп, за кожною зі шкал обраних для використання в експерименті методик, отримані дані було оброблено за допомогою tкритерію Стьюдента для незв'язаних сукупностей. В результаті було встановлено, що статистично значущих відмінностей між учасниками експериментальної та контрольної груп у досліджуваних характеристиках до експерименту не було виявлено. Це дало нам можливість стверджувати, що працівники органів внутрішніх справ, які увійшли до складу екс- 
периментальної і контрольної груп, на момент початку експерименту мали приблизно однакові особистісні характеристики. Після перевірки учасників експерименту на однорідність, 3 членами, які увійшли до складу експериментальної групи, було проведено усі заходи передбачені психолого-організаційною технологією «Розвиток конструктивної копінг-поведінки працівників органів внутрішніх справ у важких ситуаціях професійної діяльності». Після чого з учасниками $з$ експериментальної та контрольної груп було проведено другий психодіагностичний зріз. Результати статистичної обробки даних для порівняння результатів другого психодіагностичного зрізу експериментальної групи наведені у таблиці 1.

Приведені у таблиці 1 дані свідчать, що після застосування психолого-організаційної технології «Розвиток конструктивної копінгповедінки працівників органів внутрішніх справ у важких ситуаціях професійної діяльності» статистично значимі зміни відбулися за більшістю показників, що були діагностовані.

У когнітивно-оцінному компоненті найбільші зміни в бік зростання відбулися за показниками рівня самоефективності у сфері міжособистісного спілкування, інтернальності досягнень, інтернальності виробничих відносин, інтернальності міжособистісних відносин, загальної інтернальності. У мотиваційноопераційному компоненті найбільше зросли рівні прагнення до прийняття оточенням, мо- тивації досягнення успіху, показників вибору асертивної стратегії копінг-поведінки та стратегії пошуку соціальної підтримки. У регулятивному компоненті найбільші зміни в бік зростання відбулися за показниками розвиненості раціонального каналу емпатії, установок які сприяють емпатії, здатності до емпатії, ідентифікації в емпатії, сумарного показника емпатії. При цьому дещо зріс усереднений показник самооцінки особистості (Див. Таблицю 1 на наступній сторінці).

У стильових особливостях саморегуляції на статистично значимому рівні зросли показники шкал планування, моделювання, програмування, оцінки результатів, гнучкості, самостійності, загального рівня саморегуляції.

\section{Висновки і подалыші перспективи}

\section{досліджень}

Результати експериментальної перевірки дієвості психолого-організаційної технології «Розвиток конструктивної копінгповедінки працівників органів внутрішніх справ у важких ситуаціях професійної діяльності» доводять iii ефективність. Зазначена психолого-організаційна технологія є необхідним чинником успішної професіоналізації працівників органів внутрішніх справ. Найбільш оптимальним шляхом підвищення рівня конструктивності копінг-поведінки працівників органів внутрішніх справ у важких ситуаціях професійної діяльності є поєднання занять 3 удосконалення кадрів органів внутрішніх справ, розглянутої психолого- 


\section{Результати статистичної обробки показників експериментальної групи до та після експерименту}

\begin{tabular}{|c|c|c|c|c|c|}
\hline $\mathbf{H} / \mathbf{I}$ & $\begin{array}{c}\text { МХарактеристика, яка тестува- } \\
\text { лася }\end{array}$ & $\begin{array}{c}\text { Показник } \\
\text { ЕГ до експеримен- } \\
\text { ту } \\
\end{array}$ & $\begin{array}{c}\text { Показник } \\
\text { ЕГ після } \\
\text { експерименту } \\
\end{array}$ & $\mathbf{T}$ & $\mathbf{p}$ \\
\hline \multicolumn{6}{|c|}{ Когнітивно-оцінний компонент } \\
\hline 1. & $\begin{array}{l}\text { Рівень самоефективності } \\
\text { сфера міжособистісного спілку- } \\
\text { вання }\end{array}$ & $11.250 \pm 0.518$ & $11.571 \pm 0.514$ & 3.512 & $\leq 0,05$ \\
\hline \multicolumn{6}{|c|}{ Показники інтернальності-екстернальності } \\
\hline 2. & Інтернальність досягнень & $6.607 \pm 0.383$ & $6.857 \pm 0.369$ & 2.946 & $\leq 0,05$ \\
\hline 3. & $\begin{array}{l}\text { Інтернальність виробни- } \\
\text { чих відносин }\end{array}$ & $5.893 \pm 0.439$ & $6.643 \pm 0.375$ & 6.658 & $\leq 0,05$ \\
\hline 4. & $\begin{array}{l}\text { Інтернальність міжособис- } \\
\text { тісних відносин }\end{array}$ & $6.429 \pm 0.383$ & $6.821 \pm 0.323$ & 3.601 & $\leq 0,05$ \\
\hline 5. & Загальна інтернальність & $6.929 \pm 0.385$ & $7.357 \pm 0.306$ & 3.512 & $\leq 0,05$ \\
\hline \multicolumn{6}{|c|}{$\begin{array}{l}\text { Мотиваційно-операційний компонент } \\
\end{array}$} \\
\hline \multicolumn{6}{|c|}{ Стратегії подолання стресових ситуацій } \\
\hline 1. & Асертивні дії & $18.750 \pm 0.774$ & $19.964 \pm 0.594$ & 4.604 & $\leq 0,05$ \\
\hline 2. & $\begin{array}{l}\text { Вступ у соціальний кон- } \\
\text { такт }\end{array}$ & $23.464 \pm 0.565$ & $24.036 \pm 0.427$ & 2.777 & $\leq 0,05$ \\
\hline 3. & $\begin{array}{l}\text { Пошук соціальної підтри- } \\
\text { мки }\end{array}$ & $22.143 \pm 0.634$ & $22.857 \pm 0.499$ & 3.321 & $\leq 0,05$ \\
\hline 4. & Мотивація досягнення успіху & $15.536 \pm 1.012$ & $17.000 \pm 0.859$ & 7.614 & $\leq 0,05$ \\
\hline \multicolumn{6}{|c|}{ Рівень афіліації } \\
\hline 5. & $\begin{array}{l}\text { Прагнення до прийняття оточен- } \\
\text { ням }\end{array}$ & $135.607 \pm 9.321$ & $159.393 \pm 8.358$ & 8.910 & $\leq 0,05$ \\
\hline \multicolumn{6}{|c|}{ Регулятивний компонент } \\
\hline \multicolumn{6}{|c|}{ Рівень емпатія } \\
\hline 1. & Раціональний канал емпатія & $3.071 \pm 0.251$ & $3.821 \pm 0.235$ & 8.838 & $\leq 0,05$ \\
\hline 2. & Установки, які сприяють емпатії & $3.107 \pm 0.242$ & $3.250 \pm 0.260$ & 2.083 & $\leq 0,05$ \\
\hline 3. & Здатність до емпатії & $3.071 \pm 0.282$ & $3.286 \pm 0.256$ & 2.665 & $\leq 0,05$ \\
\hline 4. & Ідентифікація в емпатії & $3.214 \pm 0.269$ & $3.393 \pm 0.242$ & 2.379 & $\leq 0,05$ \\
\hline 5. & Сумарний показник емпатії & $3.179 \pm 0.267$ & $3.357 \pm 0.263$ & 2.379 & $\leq 0,05$ \\
\hline \multicolumn{6}{|c|}{ Самооцінка особистості } \\
\hline 6. & Усереднений показник & $0.475 \pm 0.055$ & $0.526 \pm 0.045$ & 2.158 & $\leq 0,05$ \\
\hline \multicolumn{6}{|c|}{ Стильові особливості саморегуляції } \\
\hline 7. & Планування & $4.714 \pm 0.291$ & $4.964 \pm 0.259$ & 2.507 & $\leq 0,05$ \\
\hline 8. & Моделювання & $5.250 \pm 0.326$ & $5.464 \pm 0.321$ & 2.665 & $\leq 0,05$ \\
\hline 9. & Програмування & $4.786 \pm 0.311$ & $5.000 \pm 0.331$ & 2.665 & $\leq 0,05$ \\
\hline 10. & Оцінка результатів & $5.607 \pm 0.279$ & $5.821 \pm 0.292$ & 2.233 & $\leq 0,05$ \\
\hline 11. & Гнучкість & $5.143 \pm 0.358$ & $5.393 \pm 0.353$ & 2.507 & $\leq 0,05$ \\
\hline 12. & Самостійність & $5.071 \pm 0.327$ & $5.286 \pm 0.339$ & 2.233 & $\leq 0,05$ \\
\hline 13. & Загальний рівень саморегуляції & $28.321 \pm 0.547$ & $28.607 \pm 0.575$ & 2.083 & $\leq 0,05$ \\
\hline
\end{tabular}


організаційної технології та стимулювання працівників до постійного особистісного та професійного саморозвитку та самовдосконалення.

Перспективними напрямами подальших досліджень копінг-поведінки працівників органів внутрішніх справ у важких ситуаціях професійної діяльності слід вважати проведення системних досліджень у парадигмі проактивногокопінгу та аналізу особистісних ресурсів, на основі яких він формується.

\section{Перелік використаних джерел:}

1. Василенко М. М. Модель застосування копінгстратегій у професійній /діяльності працівників органів внутрішніх справ України /М.М. Василенко // Юридична психологія та педагогіка - 2010 - №2. - С. 124-134.

2. Василенко М. М. Теоретичні засади дослідження стресу у професійній діяльності/М.М.Василенко// Проблеми загальної та педагогічної психології - збірник наукових праць інституту психології ім.Г.С. Костюка АПН України/ За ред..С.Д.максименка.Т.ХІ, часT2. - К.2009 - C. 74-83.

3. Грандт В. В. Копінг-ресурси як чинник збереження професійного здоров'я особистості : автореф. дис. ... канд. психол. наук : 19.00.01 / В. В. Грандт; НАПН України, Ін-т психології ім. Г.С. Костюка . - К., 2012. - 20 c.

4. Дідух М. М. До питання розвитку конструктивної копінг-поведінки працівників органів внутрішніх справ у важких ситуаціях професійної діяльності// Сучасний стан психологічного забезпечення професійної діяльності сил охорони правопорядку: зб.матеріалів Всеукраїнської науково-практичної конференції (м.Харків, 25 листопада 2016)-Національна академія НГУ. - 2016 C. 83-85.
5. Дідух М. М. Стан розвитку компонентів конструктивної копінг-поведінки у працівників органів внутрішніх справ / М.М. Дідух // Зб. наук. праць «Проблеми сучасної психології» Кам'янець-Подільського національного університету імені Івана Огієнка. - 2014 -№26.- С.129143.

6. Назаров О. О. Психологічні особливості базових копінг-стратегій та особистісних копінг-ресурсів працівників пожежно-рятувальних підрозділів МНС України : монографія / О. О. Назаров, Н. В. Оніщенко, О. В. Садковий, О. І. Склень, О. В. Тімченко; УН-т цив. захисту України. - Х., 2008. - 221 с.

7. Самара О. С. Психологічні особливості стратегій стрес-долаючої поведінки співробітників МНС: автореф. дис. ... канд. психол. наук : 19.00.01 / О.С. Самара ; Одес. нац. ун-т ім. І.І. Мечникова. - О., 2010. - 16 с.

8. Склень О. І. Психологічні особливості поведінкових стратегій подолання стресу в професійній діяльності працівників пожежно-рятувальних підрозділів МНС України: автореф. дис... канд. психол. наук: 19.00.09 / О.І. Склень ; Ун-т цив. захисту України. - Х., 2008. - 22 c.

9.Технології роботи організаційних психологів: Навч. посіб. для студентів вищ. навч. закл. та слухачів ін-тів після диплом. освіти / За наук. ред. Л. М. Карамушки. К.: Фірма «ІНКОС», 2005. - 366 с.

10. Ткачук T. А. Дослідження локусу контролю як складової копінг-поведінки фахівців податкової служби / Т. Ткачук // Соц. психологія. - 2010. - № 4. - С. 95-102.

\section{References (Transliteration):}

1.Vasylenko M. M. Model zastosuvannia kopinh-stratehii u profesiinii /diialnosti pratsivnykiv orhaniv vnutrishnikh sprav Ukrainy /M.M. Vasylenko // Yurydychna psykholohiia ta pedahohika - 2010 - №2. - S. 124-134.

2. Vasylenko M. M. Teoretychni zasady doslidzhennia stresu u profesiinii diialnosti/M.M.Vasylenko//Problemy zahalnoi ta pedahohichnoi psykholohii - zbirnyk naukovykh 
prats instytutu psykholohii im.H.S. Kostiuka APN Ukrainy/ Za red..S.D.maksymenka.T.KhI, chast2. - K.2009 - S. 7483.

3. Hrandt $V$. $V$. Kopinh-resursy yak chynnyk zberezhennia profesiinoho zdorovia osobystosti : avtoref. dys. ... kand. psykhol. nauk : 19.00.01 / V. V. Hrandt; NAPN Ukrainy, In -t psykholohii im. H.S. Kostiuka . - K., 2012. - 20 c.

4. Didukh M. M. Do pytannia rozvytku konstruktyvnoi kopinh-povedinky pratsivnykiv orhaniv vnutrishnikh sprav $u$ vazhkykh sytuatsiiakh profesiinoi diialnosti// Suchasnyi stan psykholohichnoho zabezpechennia profesiinoi diialnosti syl okhorony pravoporiadku: zb.materialivVseukrainskoi naukovo-praktychnoi konferentsii (m.Kharkiv, 25 lystopada 2016)-Natsionalna akademiia NHU. - 2016 - S. 83-85.

5. Didukh M.M. Stan rozvytku komponentiv konstruktyvnoi kopinh-povedinky u pratsivnykiv orhaniv vnutrishnikh sprav / M.M. Didukh // Zb. nauk. prats «Problemy suchasnoi psykholohii» Kamianets-Podilskoho natsionalnoho universytetu imeni Ivana Ohiienka. - 2014 -№26.- S.129143.

6. Nazarov O. O. Psykholohichni osoblyvosti bazovykh kopinh-stratehii ta osobystisnykh kopinh-resursiv pratsivnykiv pozhezhno-riatuvalnykh pidrozdiliv MNS Ukrainy : monohrafiia / O. O. Nazarov, N. V. Onishchenko, O. V. Sadkovyi, O. I. Sklen, O. V. Timchenko; Un-t tsyv. zakhystu Ukrainy. - Kh., 2008. - 221 c.

7. Samara O. Ie. Psykholohichni osoblyvosti stratehii stresdolaiuchoi povedinky spivrobitnykiv MNS: avtoref. dys. ... kand. psykhol. nauk : 19.00.01 / O.Ie. Samara ; Odes. nats. un-t im. I.I. Mechnykova. - O., 2010. - 16 s.

8. Sklen O. I. Psykholohichni osoblyvosti povedinkovykh stratehii podolannia stresu v profesiinii diialnosti pratsivnykiv pozhezhno-riatuvalnykh pidrozdiliv MNS Ukrainy: avtoref. dys... kand. psykhol. nauk: 19.00.09 / O.I. Sklen ; Un-t tsyv. zakhystu Ukrainy. - Kh., 2008. - 22 s.

9. Tekhnolohii roboty orhanizatsiinykh psykholohiv: Navch. posib. dlia studentiv vyshch. navch. zakl. ta slukhachiv in-tiv pislia dyplom. osvity / $\mathrm{Za}$ nauk. red. L. M. Karamushky. - K.: Firma «INKOS», 2005. - 366 s.
10. Tkachuk T. A. Doslidzhennia lokusu kontroliu yak skladovoi kopinh-povedinky fakhivtsiv podatkovoi sluzhby / T. Tkachuk // Sots. psykholohiia. - 2010. - № 4. - S. 95-102.

\section{Didukh Marina Nikolaevna}

Lecturer in department of psychology and pedagogy of the National Academy of Internal Affairs, Kyiv (Ukraine)

\section{RESULTS OF EXPERIMENTAL VERIFI- CATION EFFECTIVENESS OF PSYCHO- LOGICAL AND ORGANIZATIONAL TECHNOLOGIES OF THE DEVELOP- MENT OF CONSTRUCTIVE COPING CON- DUCT POLICE OFFICERS}

\section{ABSTRACT}

The article presents the results of forming experiment, which consisted in the development of evidence-based means of constructive copingbehavior of police officers in difficult situations, professional and experimental verification of their effectiveness. The basis of the special psychological and organizational technology «development of constructive coping behavior of police officers in difficult situations of professional activity», was the psychological and organizational technology offered by L.M. Karamushka. The purpose of technology is to provide a self -change and adjustment of coping behavior of the participants of the training in the direction of selection of constructive coping strategies. Experimental results show that after using psychological and organizational technologies statistically significant changes were diagnosed on most indicators. In particular, the cognitive-evaluative com- 
ponent increased rates of self-efficacy in interpersonal communication, internal achievements, industrial relations, interpersonal relations, general internal. In motivational and operational component the biggest changes in desire for acceptance environment, motivation to succeed, select assertive strategy of coping behavior and search strategies of social support. In theregulatorycomponent biggest changes in the direction of growth occurred in terms of sophistication efficient channel of empathy, attitudes that promote empathy, identification in empathy and the total index of empathy. The integrated indicators of formation of structural components coping behaviors became higher, what is also confirms the effectiveness of psychological and organizational technology and its suitability for the development of constructive coping behavior of police officers in difficult situations of their professional activity.

Key words: psychological and organizational technology, coping-behavior, constructive coping behavior, coping behavior patterns, information and semantic component technology, diagnostic and interpretative component technology, correctional and developmental component technology.

\section{Дидух Марина Николаевна}

Преподаватель кафедры психологии и педагогики Национальной академии внутренних дел, г. Киев (Украина)

\section{РЕЗУЛЬТАТЫ ЭКСПЕРИМЕНТАЛЬНОЙ ПРОВЕРКИ ЭФФЕКТИВНОСТИ \\ ПСИХОЛОГО-ОРГАНИЗАЦИОННОЙ ТЕХНОЛОГИИ ПО РАЗВИТИЮ КОНСТРУКТИВНОГО КОПИНГ- ПОВЕДЕНИЯ РАБОТНИКОВ ОРГАНОВ ВНУТРЕННИХ ДЕЛ}

Аннотация. В статье представлены результаты формирующего эксперимента, который заключался в разработке научно обоснованных средств развития конструктивности копинг-поведения сотрудников органов внутренних дел в тяжелых ситуациях профессиональной деятельности и экспериментальнойпроверки их эффективности.

В основу специальной психологоорганизационной технологии «Развитие конструктивного копинг-поведения сотрудников органов внутренних дел в тяжелых ситуацияхпрофессиональной деятельности», была положена психолого-организационная технология, предложенная Л. Н. Карамушкой.

Цель технологии заключалась в обеспечении самоизменения и корректировки копинг-поведения участников тренинга в направлении выбора конструктивных копингстратегий. Результаты эксперимента свидетельствуют, что после применения психологоорганизационной технологии статистическизначимые изменения произошли по большинству диагностируемых показателей. 
Ключевые слова: психолого-

организационная технология, копингповедение, конструктивное копинг-поведение, моделикопинг-поведения, информационносмысловой компонент технологии, диагностико-интерпретационный компонент технологии, коррекционно-развивающий компонент технологии. 